\title{
Quality Improvement of Semi-Wet Terasi by Optimizing the Starter Culture Ratio of Controlled Fermentation
}

\author{
Arisa Sato ${ }^{1,2}$, Dea Indriani Astuti ${ }^{1 *}$, Sastia Prama Putri ${ }^{1,2}$, Eiichiro Fukusaki ${ }^{2}$ \\ ${ }^{1}$ Biotechnololgy, School of Life Science and Technology, Institute of Technology Bandung, Bandung, Indonesia \\ ${ }^{2}$ Department of Biotechnology, Graduate School of Engineering, Osaka University, Japan
}

\section{ARTICLE INFO}

Article history:

Received June 30, 2020

Received in revised form September 20, 2020

Accepted September 22, 2020

\section{KEYWORDS:}

quality improvement,

terasi,

Indonesian shrimp paste,

controlled fermentation

\begin{abstract}
Terasi is a traditional fermented shrimp paste used in Indonesian dish as condiments. Due to its affordability, the paste is widely consumed among the general population, and thus has a great impact in Indonesia. Currently, smallscale or home industry is common for terasi production, and natural fermentation process is the traditional method. Fermentation process is considered complete when desired aromatic odors are obtained. However, this makes the fermentation process subjective, because the decision is solely dependent on the producer. Additionally, natural fermentation poses a higher risk for contamination of microbial pathogens. As a result, the quality of the final product varies greatly from region to region. Therefore, it is necessary to improve the quality of terasi by means of controlled fermentation. Hence, the objective of the research is to optimize the controlled fermentation condition of terasi by determining the most optimal ratio of mixed starter culture. Optimal fermentation conditions were determined by analyzing the effect of the various starter inoculum on the inner microbial community, and results indicated that mixed culture of Staphylococcus saprophyticus, Bacillus subtilis, and Lactobacillus murinus with ratio of 2:1:2 was the most effective for suppressing the growth of unwanted microorganisms. The difference in the microbial composition also resulted to a change in the metabolite profile of terasi.
\end{abstract}

\section{Introduction}

Fermented shrimp paste in Indonesia is specifically known as terasi and is commonly produced from planktonic shrimp Schizopodes spp. or Mydes spp. Terasi is served as a condiment, and the functional property of terasi is to provide salt and umami taste for the dish (Hajeb and Jinap 2012). The protein content of the shrimp paste can range from $25-66 \%$, which is significantly higher than other fermented fishery products, and the salt content is between 6 to $38 \%$ (Tambaria 2016). This research focuses on terasi because it is an important condiment consumed by a wide range of population, and thus has a great impact in Indonesia.

Terasi is usually produced on small-scale, or in and home industry is common. Typically, natural fermentation is used, and thus the process can last anywhere from few weeks to several months (Aryanta 2000; Waryono 2001; Hajeb and Jipan

\footnotetext{
* Corresponding Author

E-mail Address: dea@sith.itb.ac.id
}

2012). The fermentation period varies based on the producer's decision, and the end of fermentation is determined based on the fermentation is considered "done" complete when desired aromatic odors are obtained. However, this makes the fermentation process subjective, because the decision is solely dependent on the producer. Because the fermentation process is not uniformed, the quality, such as nutrition content and aroma, of the final product varies greatly from region to region (Tambaria 2016). Additionally, natural fermentation poses higher risk for microbial pathogens (Capozzi et al. 2017). As a result, the quality of the final product from natural fermentation varies greatly from region to region because the fermentation process is not uniformed, the quality, such as nutrition content and aroma, of the final product varies greatly from region to region (Tambaria 2016). Therefore, it is necessary to improve the quality of terasi by using controlled fermentation. Quality improvement can yield safer products, and can also help expand the terasi industry by changing the production process from small-scale to largescale. 
Starter culture for controlled fermentation of terasi has already been isolated in previous study. Starter culture includes a mixture of Staphyloccocus saprophyticus, Bacillus subtilis, and Lactobacillus murinus, and these were isolated from the natural fermentation of Cirebon terasi (Astuti et al. 2018). The ratio of these three dominant isolates has been optimized to shorten the fermentation period of dry terasi. In the market, the semi-wet form of the terasi is more commonly sold, but the ratio of the three dominant isolates has not been optimized. Optimization of the ratio is necessary for the semiwet form because it contains more moisture content, which can lead to more microbial growth (Roos 2003). Therefore, the objective of the research is to improve the quality of semi-wet terasi by determining the most optimal ratio of fermentation starter culture with Staphylococcus saprophyticus, Bacillus subtilis, and Lactobacillus murinus. Most optimal conditions will be determined by analyzing the effect of the various inoculum ratios on the inner microbial community and the metabolome profile during the fermentation process.

\section{Materials and Methods}

\subsection{Preparation of Starter Culture Inoculum for Fermentation}

Glycerol stock of S. saprophyticus, B. subtilis, and L. murinus isolated directly from terasi in previous study was used. S. saprophyticus and B. subtilis were isolated on nutrient agar (NA) plate and cultivated in nutrient broth (NB) medium. L. murinus was isolated on pantothenic acid (PTT) plate and cultivated in PTT medium. For pre-pre-culturing, bacteria colony was suspended in $50 \mathrm{ml}$ of liquid medium and cultured at room temperature for 24 hours at $125 \mathrm{rpm}$. For preculturing, bacteria were suspended in $50 \mathrm{ml}$ of liquid medium with $12 \%$ salt concentration and cultured at room temperature for 24 hours at $125 \mathrm{rpm}$. For main culture, bacteria were suspended in $150 \mathrm{ml}$ of liquid medium with $12 \%$ salt concentration and cultured at room temperature at $125 \mathrm{rpm}$ until exponential phase.

\subsection{Fermentation of Terasi}

The semi-wet terasi was prepared for fermentation based on the production process in Cangkol, Cirebon, West Java. The shrimp was first grounded into fine pieces and dried. Then, $12 \%$ salt (w/w), 10\% palm sugar $(\mathrm{w} / \mathrm{w})$, and $10 \%$ water $(\mathrm{v} / \mathrm{w})$ was added. To initiate fermentation, $10 \%(\mathrm{v} / \mathrm{W})$ of inoculum was added to the shrimp mixtures with different ratio of starter culture, as indicated in Table 1, under an aseptic condition. Natural fermentation indicates shrimp mixture without inoculum culture. Then, the shrimp mixture was fermented in a plastic jar with aluminum-covered lid at room temperature for a period of 28-days. Three biological replicates were conducted for each fermentation conditions.

\subsection{Conducting Time-Course Sampling}

To monitor the fermentation process, $50 \mathrm{~g}$ of the sample is taken from the plastic jar under aseptic condition for each sampling point. During the 28day fermentation period, a total of five sampling was carried out on day $0,7,14,21$, and 28 . Samples for microbial community dynamics analysis was stored at $4^{\circ} \mathrm{C}$, while samples used for metabolomics analysis was stored in $-20^{\circ} \mathrm{C}$ to prevent changes in metabolites.

\subsection{Microbial Dynamics Analysis using Three Different Agars}

$1 \mathrm{~g}$ of sampled terasi was homogenized in $9 \mathrm{ml}$ of $0.1 \%$ peptone water to create a 10 -fold dilution. Then, the sample was diluted further using $0.1 \mathrm{ml}$ of the previous dilution fold with $0.9 \mathrm{ml}$ of $0.1 \%$ peptone water. For each sample, $100 \mu$ of the appropriate dilution of the terasi solution was plated on the NA plate, PTT plate, and eosin-methylene blue (EMB) plate. NA plate and EMB plate were incubated at $37^{\circ} \mathrm{C}$ for 24 hours, while PTT was incubated at $37^{\circ} \mathrm{C}$ for 48 hours. Then, the microbial community dynamics analysis was carried out by counting the bacteria plate, and the bacteria are microscopically identified.

\subsection{Non-Targeted Metabolomics Analysis using GC/MS}

Sample terasi were made into powder-form by lyophilizing and crushing, using Multi-bead shocker ${ }^{\circledR}$ (Yasui Kikai, Japan). Then, $1 \mathrm{ml}$ of $80 \%$ methanol with ribitol (used as internal standard;

Table 1. Inoculum ratio of S. saprophyticus, B. subtilis, and L. murinus

\begin{tabular}{|c|c|c|c|}
\hline & S. saprophyticus & B. subtilis & L. murinus \\
\hline Natural & - & - & - \\
\hline Terasi A & 1 & 1 & 1 \\
\hline Terasi B & 1 & 2 & 2 \\
\hline Terasi C & 2 & 1 & 2 \\
\hline
\end{tabular}


$100 \mu \mathrm{l} / \mathrm{ml}$ ) was added to $10 \mathrm{mg}$ of powedered terasi sample. The samples were incubated in the shaker incubator at $1,200 \mathrm{rpm}$ at $37^{\circ} \mathrm{C}$ for 20 minutes. After incubation, the samples were centrifuged at 10,000 $\mathrm{rpm}$ at $4^{\circ} \mathrm{C}$ for 10 minutes to pellet down the proteins and other big particles in the solution. Then, $200 \mu \mathrm{l}$ of supernatant was concentrated using centrifugal concentrator at $150 \mathrm{rpm}$ at $25^{\circ} \mathrm{C}$ for 90 minutes to remove the organic solvents, and lyophilized for 12 hours to remove the water content. Next, the samples were derivatized. For oxyimation reaction, $100 \mu \mathrm{l}$ of $20 \mathrm{mg} / \mathrm{ml}$ of methoxyamine hydrochloride in pyridine neat was added to the sample and incubated in shaker incubator at $1,200 \mathrm{rpm}$ at $30^{\circ} \mathrm{C}$ for 90 minutes. For silyation reaction, $50 \mu \mathrm{l}$ of N-Methyl$\mathrm{N}$-(trimethylsilyl) trifluoroacetamide (MSTFA) was added and incubated in shaker incubator at 1,200 $\mathrm{rpm}$ at $37^{\circ} \mathrm{C}$ for 30 minutes. Gas chromatography/ mass spectrometry (GC/MS) analysis was carried out using GCMS-QP2010 (Shimadzu, Japan) with InterCap® 5MS/NP (30 mm x 0.25 mm I.D., df.=0.25 $\mu \mathrm{m}$; GL Sciences, Japan) for column. A total of $1 \mu \mathrm{l}$ was injected.

\subsection{Proximate Analysis}

Proximate analysis was conducted by PT. Sarawanti Indo Genetech by referring to SNI 01-2891-1992. The analysis quantified the content of carbohydrate, protein, fat, water, and ash. For the purpose of this research, only one biological replicate was used.

\section{Results}

\subsection{Changes in Microbial Community During Terasi Fermentation}

Most optimum fermentation condition was determined based on the ratio of starter culture that suppressed the growth of indigenous microbes the most. NA plate was used to monitor nonfastidious microorganisms, PTT plate was used to monitor Lactobacillus species, and EMB plate was used to check for the presence of coliform bacteria.

\subsubsection{Change in Microbial Community of Non- Fastidious Bacteria on NA Plate}

For naturally fermented terasi, the raw material was not inoculated with any starter culture. The total microbial count decreased from 5.41 to $4.83 \log$ CFU $\mathrm{ml}^{-1}$, and the indigenous bacteria count decreased from 4.63 to $4.54 \log$ CFU ml-1 (Table 2). The relative abundance of S. saprophyticus decreased until day 21 and increase slightly at the end, while the relative abundance of $B$. subtilis decreased until day 14, and increased again from day 14 to day 28 (Figure 1 ). On day $28, B$. subtilis and S. saprophyticus together dominates $49.6 \%$ of the microbial population.

Table 2. Quantification of microorganisms from NA plate analysis. Percentage decrease of indigenous bacterria was calculated based on difference of CFU ml-1 count from Day 0 and Day 28. Average decrease rate of indigenous bacteria was calculated based on of CFU ml-1 count from Day 0 and Day 28 and divided by the fermentation period

\begin{tabular}{|c|c|c|c|c|c|c|c|c|}
\hline & \multicolumn{2}{|c|}{ Natural } & \multicolumn{2}{|c|}{ Terasi A } & \multicolumn{2}{|c|}{ Terasi B } & \multicolumn{2}{|c|}{ Terasi C } \\
\hline & Day 0 & Day 28 & Day 0 & Day 28 & Day 0 & Day 28 & Day 0 & Day 28 \\
\hline $\begin{array}{l}\text { Total bacteria } \\
(\log \text { CFU ml-1 })\end{array}$ & 5.41 & 4.83 & 5.81 & 4.81 & 5.95 & 4.78 & 6.10 & 4.77 \\
\hline $\begin{array}{l}\text { Total indigenous } \\
\text { bacteria (log } \\
\text { CFU ml-1) }\end{array}$ & 4.63 & 4.54 & 5.43 & 4.58 & 5.92 & 4.23 & 6.07 & 4.40 \\
\hline $\begin{array}{l}\text { Percentage } \\
\text { decrease of } \\
\text { indigenous } \\
\text { bacteria (\%) }\end{array}$ & 82 & & 86 & & 98 & & 98 & \\
\hline $\begin{array}{l}\text { Average decrease } \\
\text { rate of } \\
\text { indigenous } \\
\text { bacteria (log } \\
\text { CFU ml }{ }^{-1} / \text { day) }\end{array}$ & 2.5 & & 3.9 & & 4.4 & & 4.6 & \\
\hline
\end{tabular}


Natural

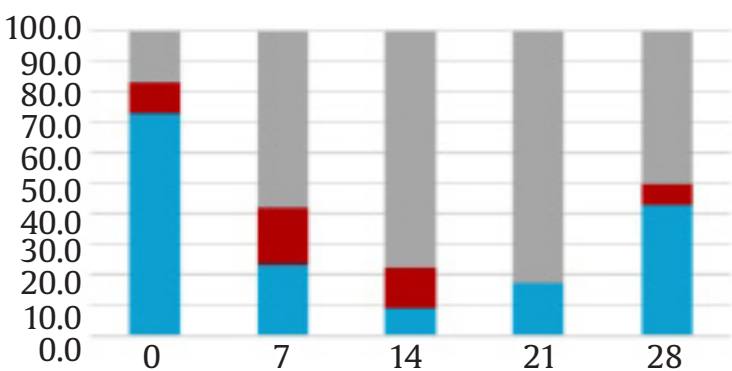

Terasi B

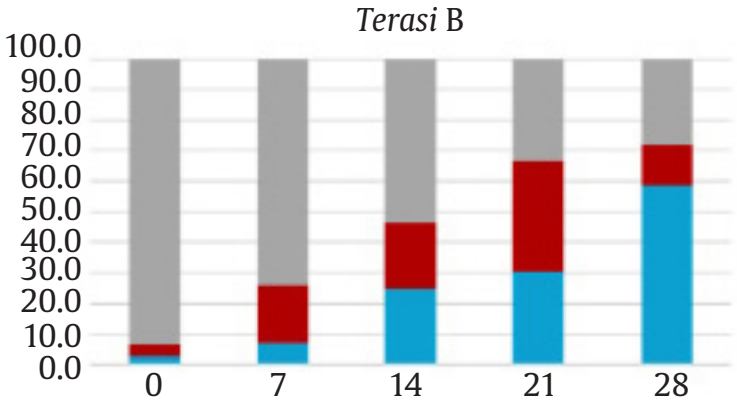

Terasi A
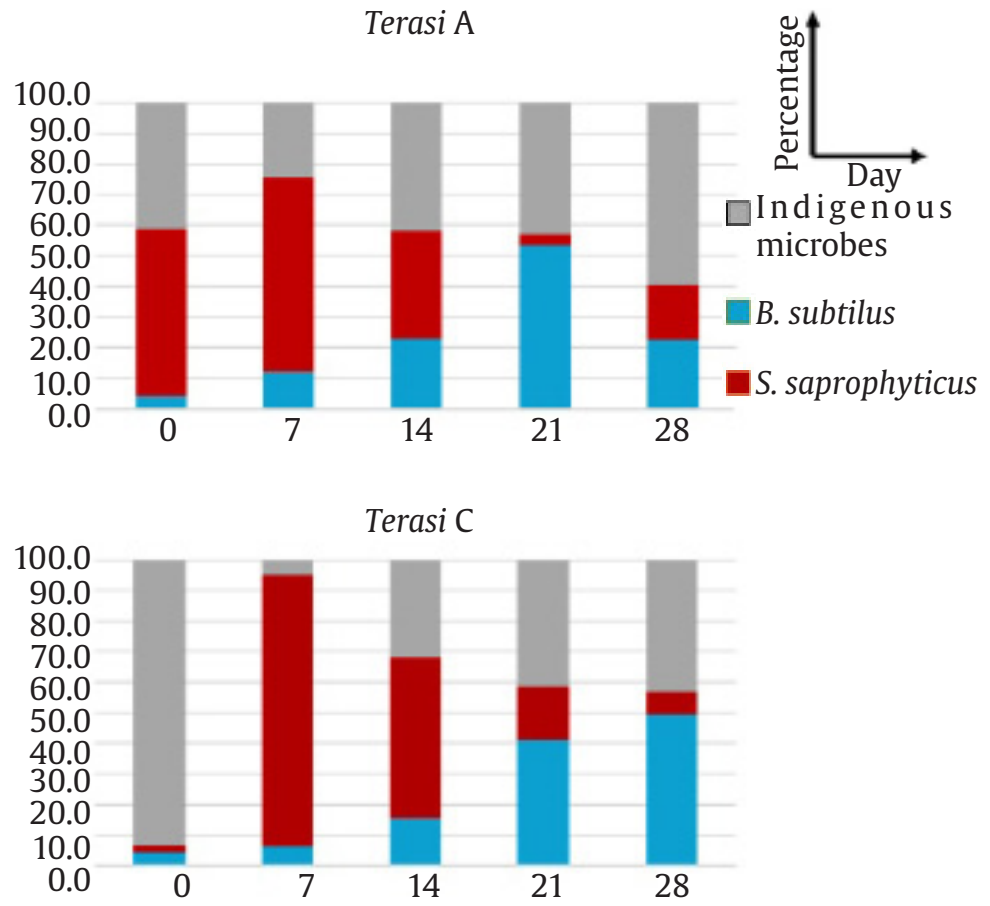

Figure 1. Relative abundance of microorganisms on NA plate. Gray indicates indigenous microbes, blue indicates B. subtilis, and red indicates $S$. saprophyticus. The y-axis is the percentage, with $100 \%$ as the maximum, and the $\mathrm{x}$-axis indicates day 0, day 7, day 14, day 21, and day 28. Natural refers to fermentation without inoculum. Controlled fermentation was inoculated with S. saprophyticus, B. subtilis, and L. murinus in Terasi A with 1:1:1, Terasi B with $1: 2: 2$, Terasi $C$ with $2: 1: 2$, respectively

For terasi $\mathrm{A}$, the total bacterial count decreased from 5.81 to $4.81 \log \mathrm{CFU} \mathrm{ml} \mathrm{m}^{-1}$, and the indigenous bacteria count decreased from 5.43 to $4.58 \log$ CFU $\mathrm{ml}^{-1}$ (Table 2). Overall, both quantitative bacteria count of B. subtilius and S. saprophyticus decreased throughout fermentation, and on day $28, B$. subtilis and S. saprophyticus together dominates $40.2 \%$ of the microbial population (Figure 1).

For terasi $\mathrm{B}$, the total bacterial count decreased from 5.95 to $4.78 \log \mathrm{CFU} \mathrm{ml} \mathrm{m}^{-1}$, and the indigenous bacteria count decreased from 5.92 to 4.23 log CFU $\mathrm{ml}^{-1}$ (Table 2). The quantitative count of $B$. subtilis was constant through fermentation while $S$. saprophyticus decreased. On day 28, B. subtilis and S. saprophyticus together dominates $72.2 \%$ of the microbial population (Figure 1).

For terasi $\mathrm{C}$, the total bacterial count decreased from 6.10 to $4.77 \log \mathrm{CFU} \mathrm{ml}{ }^{-1}$, and the indigenous bacteria count decreased from 6.07 to $4.40 \log$ CFU $\mathrm{ml}^{-1}$ (Table 2). Overall, both quantitative bacteria count of B. subtilius and S. saprophyticus decreased throughout fermentation, and on day 28 , B. subtilis and S. saprophyticus together dominates $56.8 \%$ of the microbial population.

\subsubsection{Change in Mmicrobial Community of Lactic Acid Bacteria On PTT Plate}

For naturally fermented terasi, the total bacterial count decreased from 5.29 to $4.48 \log \mathrm{CFU} \mathrm{ml}^{-1}$, and the indigenous bacteria count decreased from 5.25 to $4.09 \log \mathrm{CFU} \mathrm{ml}{ }^{-1}$ (Table 3 ). The relative abundance of indigenous bacteria decreased significantly in the last seven days, and on day $28, L$. murinus makes up $58.8 \%$ of the population.

For terasi $\mathrm{A}$, the total bacterial count decreased from 5.95 to $4.49 \log \mathrm{CFU} \mathrm{ml} \mathrm{m}^{-1}$, and the indigenous bacteria count decreased from 5.92 to $4.33 \log$ CFU ml ${ }^{-1}$ (Table 3). At the end of fermentation, the indigenous population dominates the population, and $L$. murinus only makes up $30.5 \%$ of the population (Figure 2 ).

For terasi $\mathrm{B}$, the total bacterial count decreased from 5.98 to $4.44 \log \mathrm{CFU} \mathrm{ml}{ }^{-1}$, and the indigenous bacteria count decreased from 5.97 to $4.01 \log$ CFU $\mathrm{ml}^{-1}$ (Table 3 ). The relative abundance of $L$. murinus 
Table 3. Quantification of microorganisms from PTT plate analysis. Percentage decrease of indigenous bacterria was calculated based on difference of CFU ml-1 count from Day 0 and Day 28. Average decrease rate of indigenous bacteria was calculated based on of CFU ml-1 count from Day 0 and Day 28 and divided by the fermentation period

\begin{tabular}{|c|c|c|c|c|c|c|c|c|}
\hline & \multicolumn{2}{|c|}{ Natural } & \multicolumn{2}{|c|}{ Terasi A } & \multicolumn{2}{|c|}{ Terasi B } & \multicolumn{2}{|c|}{ Terasi C } \\
\hline & $\overline{\text { Day } 0}$ & Day 28 & Day 0 & Day 28 & Day 0 & Day 28 & Day 0 & Day 28 \\
\hline $\begin{array}{l}\text { Total bacteria } \\
(\log \text { CFU ml-1) }\end{array}$ & 5.29 & 4.48 & 5.95 & 4.49 & 5.98 & 4.44 & 6.05 & 4.58 \\
\hline $\begin{array}{l}\text { Total indigenous } \\
\text { bacteria (log } \\
\text { CFU ml-1) }\end{array}$ & 5.25 & 4.09 & 5.92 & 4.33 & 5.97 & 4.01 & 6.04 & 4.11 \\
\hline $\begin{array}{l}\text { Percentage } \\
\text { decrease of } \\
\text { indigenous } \\
\text { bacteria (\%) }\end{array}$ & 93 & & 97 & & 99 & & 99 & \\
\hline $\begin{array}{l}\text { Average decrease } \\
\text { rate of } \\
\text { indigenous } \\
\text { bacteria (log } \\
\text { CFU ml-1/day) }\end{array}$ & 3.7 & & 4.4 & & 4.5 & & 4.5 & \\
\hline
\end{tabular}

Natural

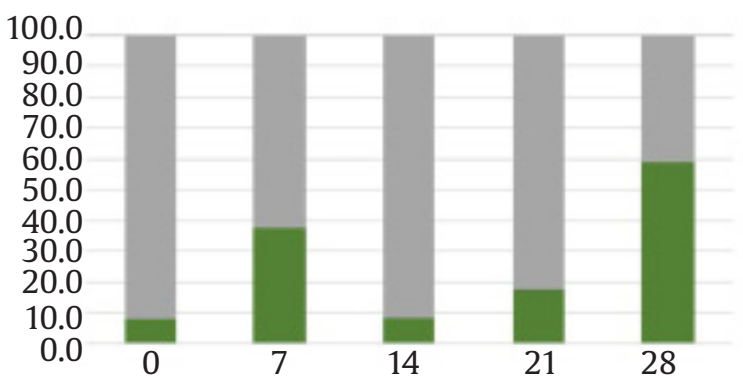

Terasi B

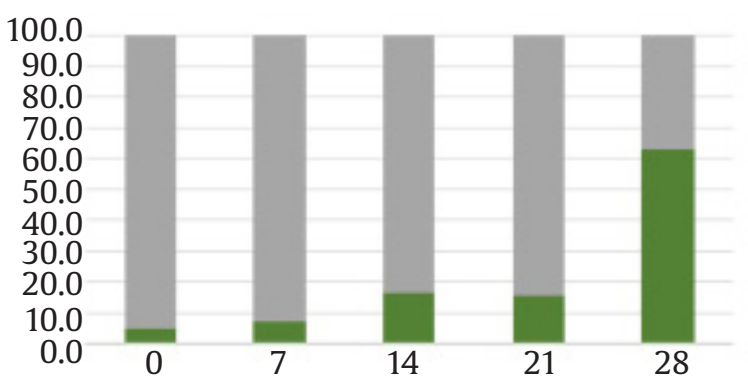

Terasi A

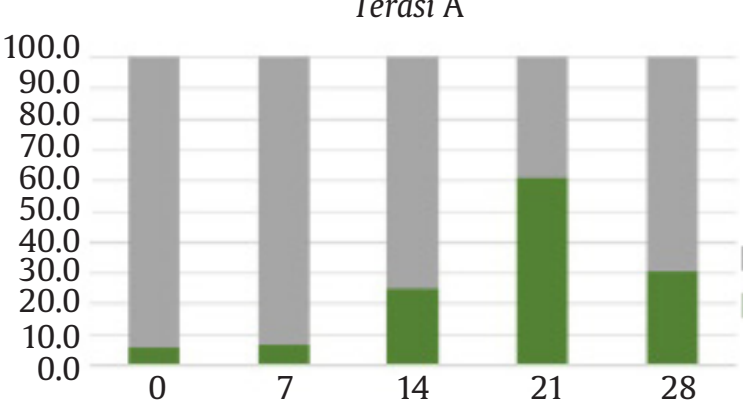

Terasi C

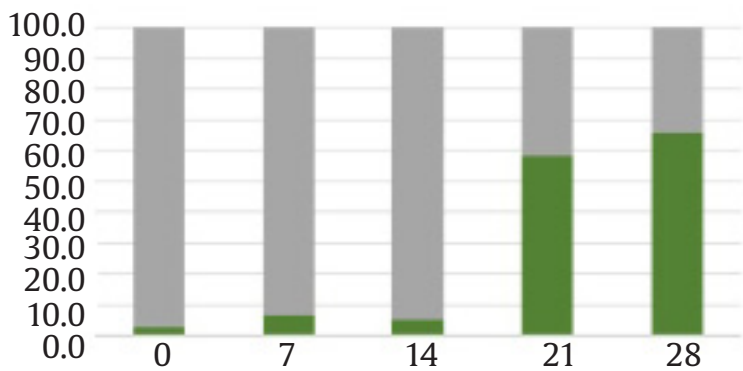

Figure 2. Relative abundance of microorganisms on PTT plate. Gray indicates indigenous microbes, and green indicates $L$. murinus. The y-axis is the percentage, with $100 \%$ as the maximum, and the $\mathrm{x}$-axis indicates day 0 , day 7 , day 14 , day 21, and day 28. Natural refers to fermentation without inoculum. Controlled fermentation was inoculated with S. saprophyticus, B. subtilis, and L. murinus in Terasi A with $1: 1: 1$, Terasi B with 1:2:2, Terasi C with 2:1:2, respectively 
is steady from day 0 to day 21 , and increased greatly between day 21 to day 28 (Figure 2). On day 28, $L$. murinus makes up $63.1 \%$ of the population, even though the quantitative number of $L$. murinus decreased throughout fermentation.

For terasi $\mathrm{C}$, the total bacterial count decreased from 6.05 to $4.58 \log \mathrm{CFU} \mathrm{ml}{ }^{-1}$, and the indigenous bacteria count decreased from 6.04 to $4.11 \log$ CFU $\mathrm{ml}^{-1}$ (Table 3). The relative abundance of $L$. murinus is steady from day 0 to day 14 , and increased greatly between day 14 to day 21 (Figure 2). In the end, $L$. murinus dominates, and makes up $65.8 \%$ of the population, even though the quantitative number of L. murinus decreased throughout fermentation.

\subsubsection{Checking for the Presence of Coliform Bacteria on EMB Plate}

EMB plate was used to assess the presence of coliform bacteria. Coliform count is used as an indicator for the hygienic conditions in food production, and high coliform count can mean unsanitary conditions. In all terasi samples, fortunately, coliform bacteria were not detected throughout the 28 days of fermentation-this includes both the terasi that was fermented naturally, and the terasi that was fermented with starter cultures.

\subsection{Change in Metabolites During Fermentation of Terasi}

From non-targeted GC/MS analysis, a total of 94 metabolites were annotated, as listed in Table 4, and non-targeted analysis was carried out to characterize the change in metabolites during fermentation. The most abundant group of compounds includes sugars, amino acids and peptides, fatty acids, and organic acids.

For all fermentation conditions, the samples from day 0 , day 7 , day 14 , day 21 , and day 28 clustered separately in the score plot (Figure 3a, c, e, g). This indicates that the metabolites changed during the fermentation from day 0 to day 28 . In the loading plot for naturally fermented terasi, there are more metabolites on the positive axis along PC2, which corresponds to day 21 and day 28 samples (Figure $3 b$ ). For terasi A and B, most of the detected metabolites, includingaminoacidssugarcompounds, organicacids, and fatty acids, accumulates towards the positive axis of PC1. This indicates that the detected metabolites are produced towards the end of fermentation (Figure 3d, f). For terasi C, the metabolites gradually accumulate from day 14 until day 28 (Figure $3 \mathrm{~h}$ ). This could indicates that polymers break down into monomers during the earlier period of fermentation.

Table 4. List of 94 metabolites annotated from terasi using GC/MS

\begin{tabular}{l} 
Sugar \\
\hline Arabitol \\
Fructose \\
Galactoseamine \\
Gluconic acid \\
Glucosamine \\
Glyceric acid \\
Glycerol \\
Lyxose \\
Maltose \\
Maltotriose \\
Mannitol \\
Panose \\
Psicose \\
Ribose \\
Sorbose \\
Sucrose \\
Tagatose \\
Threonic acid \\
Trehalose \\
Turanose \\
Xylitol \\
Xylonic acid
\end{tabular}

\begin{tabular}{l}
\multicolumn{1}{c}{ Amino acids } \\
\hline 2-aminoadipic acid \\
2-aminobutyric acid \\
5-oxoproline \\
Alanine \\
Asparagine \\
Aspartic acid \\
Glutamic acid \\
Glutamine \\
Glycine \\
Glycine-glycine \\
Histidine \\
Homocysteine \\
Homoserine \\
Iminodiacetate \\
Isoleucine \\
Nucleosides and \\
nucleotides \\
\hline 2-deoxyinosine \\
Guanosine \\
Inosine \\
Uridine
\end{tabular}

\begin{tabular}{|l|}
\hline Fatty acids \\
\hline Behenic acid \\
Elaidic acid \\
Icosanoic acid \\
Lauric acid \\
Myristic acid \\
Oleic acid \\
Palmitoleic acid \\
Pentadecanoic acid \\
Plamitic acid \\
Steraic acid \\
\hline Organic acids \\
\hline 2-hydroxybutyrate \\
Fumaric acid \\
Glycolic acid \\
Hypotaurine \\
Lactic acid \\
Malic acid \\
Taurine \\
Urea \\
\hline
\end{tabular}

\begin{tabular}{|l|}
\multicolumn{1}{|c|}{$\begin{array}{c}\text { Heterocyclic } \\
\text { compounds }\end{array}$} \\
\hline 2-hydroxypyridine \\
Guanine \\
Hypoxanthine \\
Nicotinic acid \\
Thymine \\
Uracil \\
Uric acid \\
Urocanate \\
Xanthine \\
Others \\
\hline 3-phenyllactic acid \\
4-hydroxybenzoic acid \\
Inositol \\
Quinic acid
\end{tabular}

\begin{tabular}{l} 
Leucine \\
Lysine \\
Methionine sulfoxide \\
Methionine \\
N-Acetyl valine \\
Ornithine \\
Phenylalanine \\
Proline \\
Pyroglutamic acid \\
Sarcosine \\
Serine \\
Threonine \\
Tryptophan \\
Tyrosine \\
Valine \\
\hline Amines \\
\hline 1,3-propanediamine \\
2-aminoethanol \\
Cadaverine \\
n-Butylamine \\
n-Propylamine \\
Putrescine
\end{tabular}



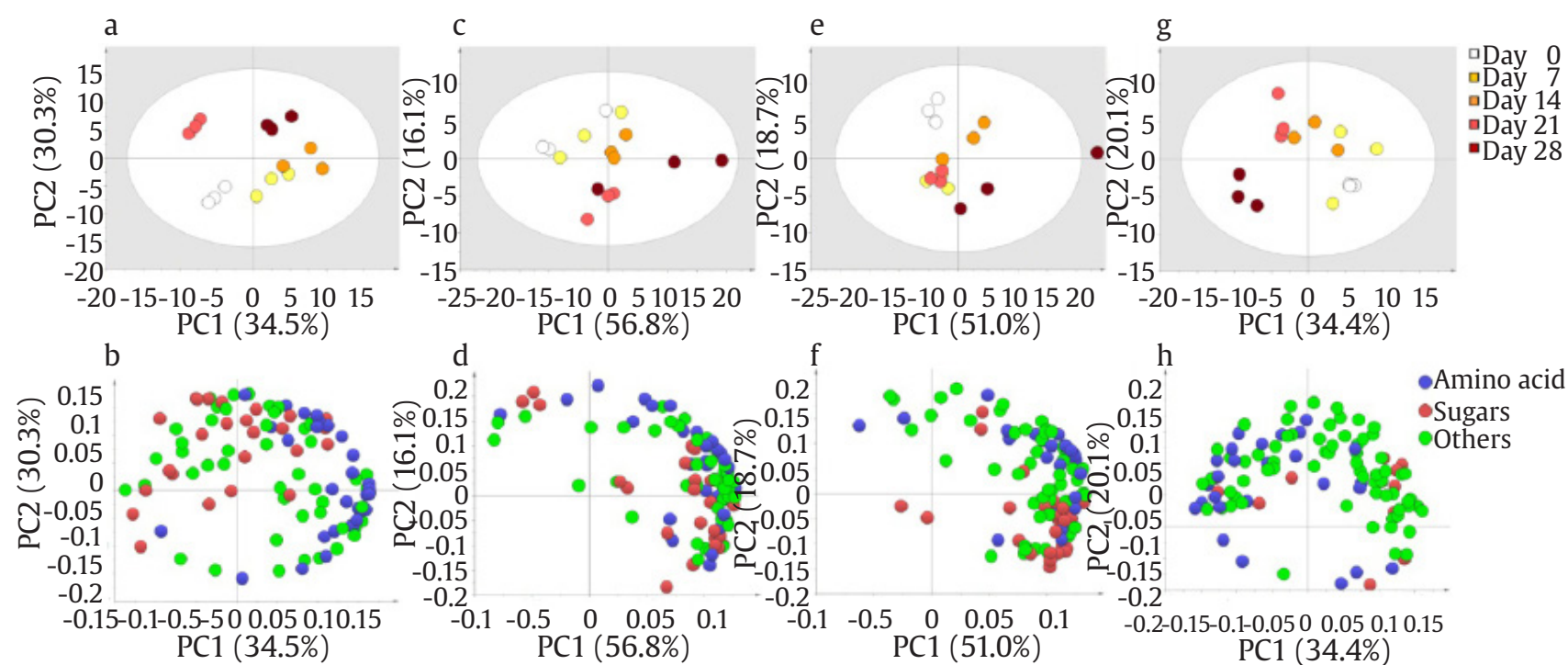

Amino acid

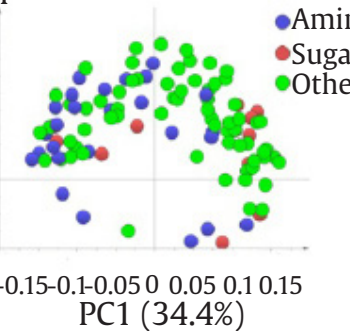

Figure 3. PCA score plot and loading plot for naturally fermented terasi $(\mathrm{a}, \mathrm{b})$, terasi $\mathrm{A}(\mathrm{c}, \mathrm{d})$, terasi $\mathrm{B}(\mathrm{e}, \mathrm{f})$, and terasi $\mathrm{C}(\mathrm{g}, \mathrm{h})$, respectively. In the score plot, white is day 0 , yellow is day 7 , orange is day 14 , red is day 21 , and dark red is day 28. In the loading plot, amino acids are colored in purple, sugar compounds are colored in red, and other metabolites are colored in green. (Scaling: auto, transformation: none, replicate: $n=3$, ellipse: Hotelling's T2 (95\%)).

In general, most of the essential amino acids increased or were constant during fermentation (Figure 4). Aspartic acid is the onlye (?) amino acid that significantly increase in all four fermentation conditions. In addition, in terasi $\mathrm{A}$, glutamic acid, lysine, serine, tyrosine, and valine also significantly increased. Interestingly, in terasi C, glycine histidine, lysine, phenylalanine, proline, serine, threonine, and valine significantly decreased. On the other hand, asparagine, glutamine, and methionine decreased in all four fermentation conditions (Figure 5).

Similar to amino acids, sugars also showed an increase towards the end of fermentation (Figure 6). The three most abundant sugar in terasi samples were glucose, glycerol, and fructose. Glucose significantly decreased in terasi C, while glucose increased in other fermentation conditions. Glycerol and fructose increased in all fermentation conditions.

\subsection{Proximate Analysis of Terasi During Fermentation}

In the final product, terasi $\mathrm{C}$ has the lowest carbohydrate content, which indicates that more amount of carbohydrate was broken down into sugars. Terasi A has the lowest protein content, while terasi $\mathrm{B}$ and terasi $\mathrm{C}$ contain more protein content than the naturally fermented terasi. Terasi A also has the lowest fat content, but terasi $\mathrm{B}$ and terasi $\mathrm{C}$ also have lower fat content than the naturally fermented terasi. Terasi $\mathrm{B}$ has the lowest moisture content, while terasi $\mathrm{C}$ has the highest moisture content. The moisture content can be related to the soft texture of terasi $\mathrm{C}$.

\section{Discussion}

Optimum fermentation condition was determined based on the ratio of starter culture that suppressed the growth of indigenous microbes the most. The EMB plate analysis indicated that all terasi product was safe because coliform bacteria were no detected. From NA plate and PTT plate microbial dynamics analysis, terasi $\mathrm{A}$, terasi $\mathrm{B}$, and terasi $\mathrm{C}$, showed a higher percentage decrease of indigenous bacteria compared to naturally fermented terasi (Table 2 and 3 ). This indicates that inoculating the raw material with starter culture is effective in suppressing the growth of indigenous bacteria. However, among the three controlled fermentation conditions, terasi $\mathrm{C}$ was the most optimum because terasi $\mathrm{C}$ had the fastest decrease rate of indigenous microbes (Table 2 and 3 ). To conclude, fermentation condition for terasi C, which was inoculated with a ratio of $2: 1: 2$ of $S$. saprophyticus, B. subtilis, and L. murinus, respectively, was the most optimal ratio.

The starter cultures are effective for suppressing the growth of the indigenous microbes because 

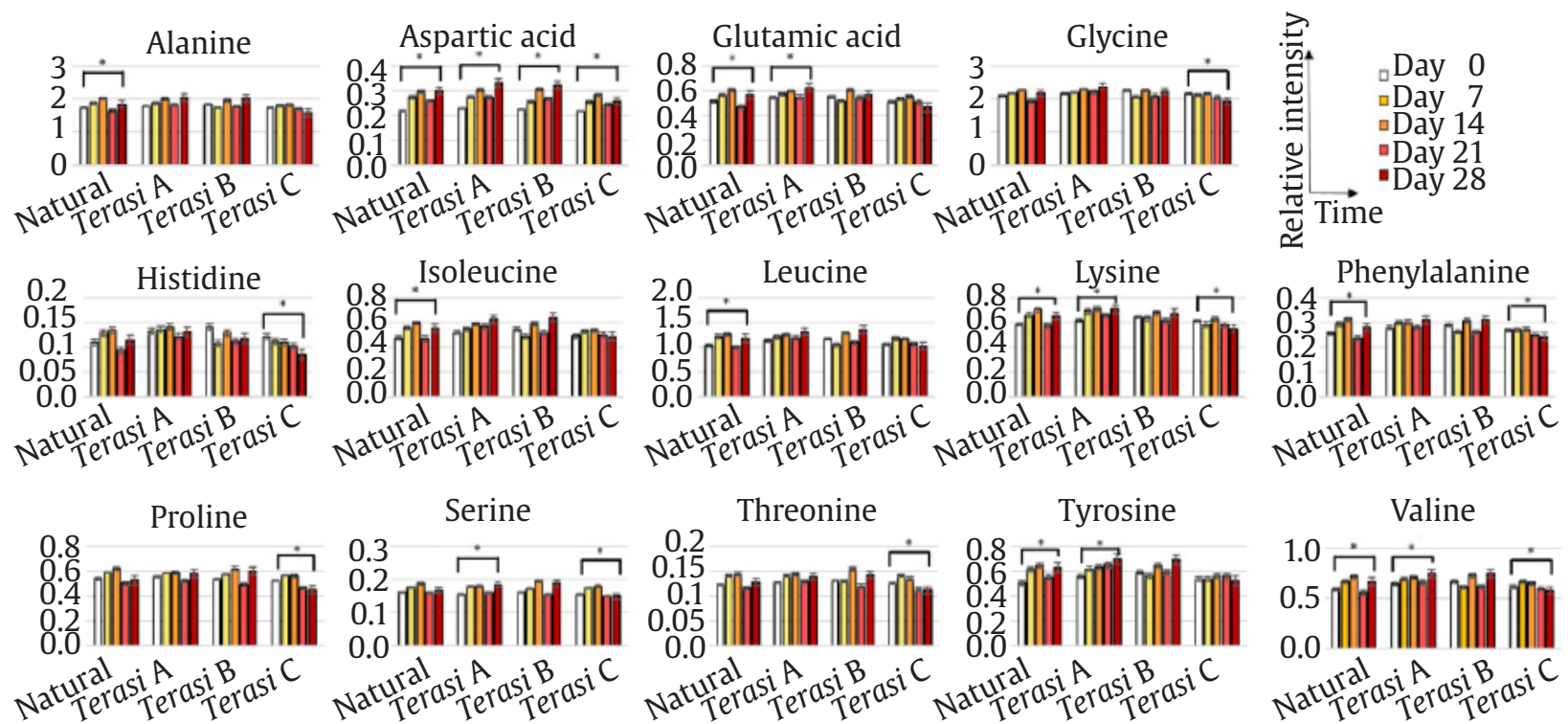

${ }^{*} p<0.05$ (Student t-test, one-tailed)

Figure 4. Univariate analysis for essential amino acids that increased or stayed constant throughout fermentation. The bar graph shows the relative intensity, and white is day 0 , yellow is day 7 , orange is day 14 , red is day 21 , and dark red is day 28

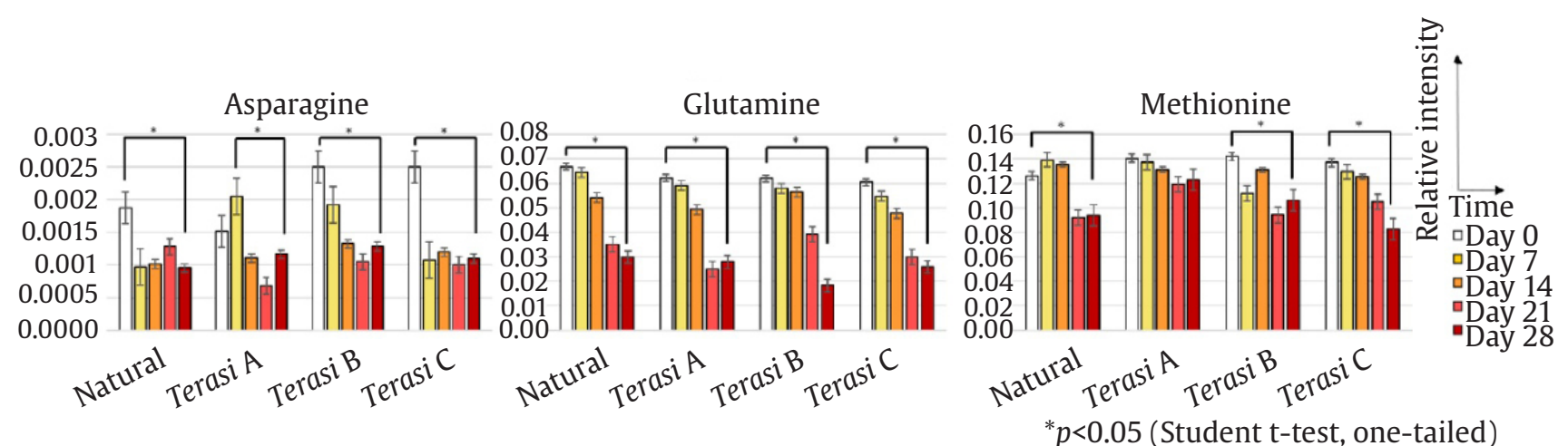

Figure 5. Univariate analysis for essential amino acids that decreased throughout fermentation. The bar graph shows the relative intensity, and white is day 0 , yellow is day 7 , orange is day 14 , red is day 21 , and dark red is day 28

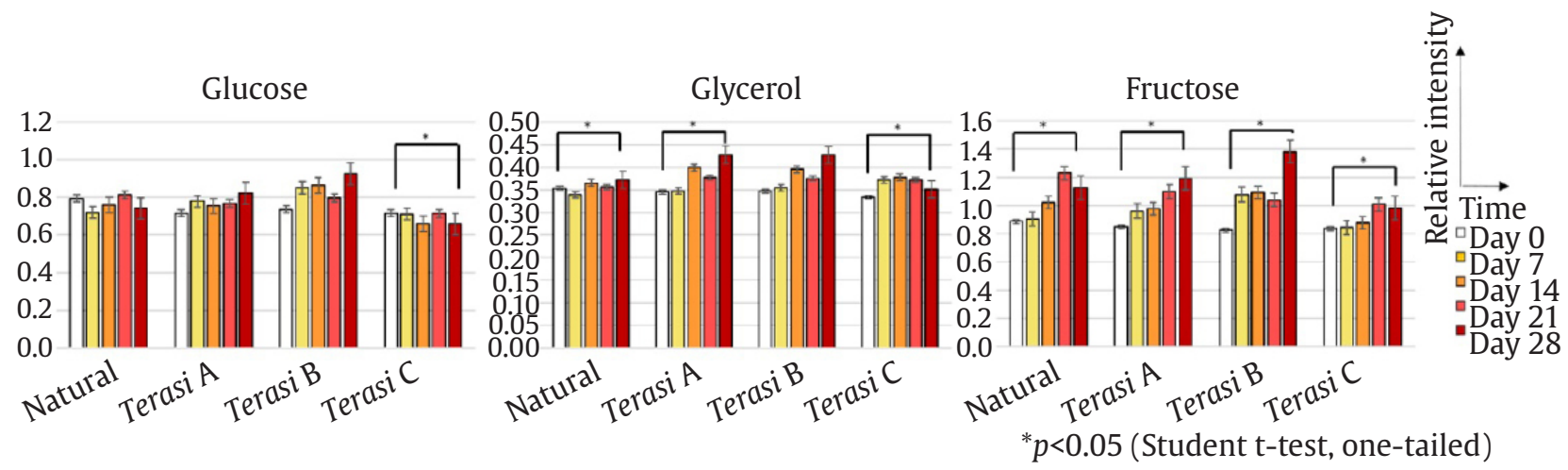

Figure 6. Univariate analysis for essential amino acids that decreased throughout fermentation. The bar graph shows the relative intensity, and white is day 0 , yellow is day 7 , orange is day 14 , red is day 21 , and dark red is day 28 
all three bacteria have antimicrobial activities. For instance, S. saprophyticus produces enzyme that is capable of suppressing the growth of grampositive and gram-negative bacteria (Hovelius and Mardh 1984). Furthermore, B. subtilis is known for producing many types of antibiotics, and have been found to produce antimicrobial peptides during fermentation of foods (Stein 2005; Cheng et al. 2017). The antimicrobial activity of B. subtilis can account for the effectiveness of using $B$. subtilis as a starter. The lactic acid bacteria, $L$. murinus, produces extracellular organic acid during fermentation that can suppresses the growth of microbes (Rhee et al. 2011). Additionally, L. murinus are known to produce bacteriocin, which inhibits the growth of both grampositive and gram-negative bacteria (Elayaraja 2014). Taken altogether, the antibacterial effect of all three starters had a role in suppressing the growth of other bacteria.

For metabolomics analysis, the concept of nontargeted analysis was to identify the metabolites in the samples and provide a non-biased, global view of the sample. From the PCA loading plot, terasi A and terasi B show similar trend. where the metabolite accumulates greatly towards day 28 of fermentation (Figure 3d and f). However, for terasi $\mathrm{C}$, the metabolites gradually accumulate from day 14 until day 28 (Figure 3h). In other words, terasi C shows completely different trends from terasi $\mathrm{A}$ and terasi $\mathrm{B}$, and this indicates that terasi $\mathrm{C}$ has a different metabolite profile compared to the naturally fermented terasi, terasi $\mathrm{A}$, and terasi $\mathrm{B}$. The difference could possibly be accounted by the extracellular activity of the starter cultures. $S$. saprophyticus have surface-associated proteins with extracellular lipase activity, whereas $B$. subtilius produce extracellular protease that breaks down proteins into amino acids (Sakinc et al. 2005; Mok et al. 2019).

During the fermentation of terasi, most of the essential amino acids increased with the exception of asparagine, glutamine, and methionine. Previously, it has been reported that aspartic acid and glutamic acid are involved in the biosynthesis of antibiotic molecule production in B. subtilis (Majumdar and Bose 1958). Therefore, one possibility for the decreased in asparagine and glutamine is that the compounds are converted to aspartic acid and glutamic acid, respectively, and the converted structures are used for biosynthesis of antibiotic molecules. More specifically, aspartic acid and glutamic acid could be involved in the biosynthesis of antibiotic iturin (Besson et al. 1990).

From proximate analysis of the final product, the moisture content is between $28.48-32.19 \%$, protein content is between $25.56-26.84 \%$, and carbohydrate content is between 24.24-28.05\% (Table 5). The moisture content and protein content follows the Indonesian National Standard (SNI) from 2016, and is also in agreement with previous studies (Aryanta 2000). However, the carbohydrate content is slightly higher than the SNI, which states between $12-20 \%$. Compared to other fermented shrimp products in Southeast Asia, the moisture content is relatively low, protein content is comparable, and the carbohydrate content is relatively high (Kim et al. 2014; Pongsetkul et al. 2014).

In conclusion, the optimized fermentation starter culture ratio of $2: 1: 2$ of $S$. saprophyticus, B. subtilis, and L. murinus, respectively, can be used to suppress the growth of unwanted microorganisms. The optimized ratio eliminates the indigenous microbes at a faster rate than natural fermentation, and can lead to improved quality of the final product.

Table 5. Proximate test results for terasi during fermentation $(n=1)$

\begin{tabular}{|c|c|c|c|c|c|}
\hline Sample & Carbohydrate (\%) & Protein (\%) & Fat (\%) & Water (\%) & Ash (\%) \\
\hline \multicolumn{6}{|c|}{ Day 0} \\
\hline Natural & 26.02 & 25.68 & 2.41 & 30.97 & 14.92 \\
\hline \multicolumn{6}{|c|}{ Day 7} \\
\hline Natural & 26.79 & 26.60 & 1.78 & 30.18 & 14.65 \\
\hline Terasi A & 26.28 & 26.45 & 1.54 & 30.96 & 14.77 \\
\hline Terasi B & 24.59 & 26.65 & 2.10 & 30.12 & 16.54 \\
\hline Terasi C & 24.74 & 26.97 & 2.52 & 30.44 & 15.33 \\
\hline \multicolumn{6}{|c|}{ Day 28} \\
\hline Natural & 28.05 & 25.79 & 2.07 & 29.07 & 15.02 \\
\hline Terasi A & 27.92 & 25.56 & 0.98 & 30.22 & 15.32 \\
\hline Terasi B & 26.06 & 27.68 & 1.70 & 28.48 & 16.08 \\
\hline Terasi C & 24.24 & 26.84 & 1.41 & 32.19 & 15.32 \\
\hline
\end{tabular}




\section{References}

Aryanta WR. 2000. Traditional fermented foods in Indonesia. Japanese Journal of Lactic Acid Bacteria 10:90-102.

Astuti et al. 2018. Physiological profiling and microorganism community analysis of Cirebon shrimp paste fermentation "Terasi" using BIOLOGTM EcoPlate. Microbiology Indonesia 12:15-22.

Besson et al. 1990. Studies on the biosynthesis of iturin, an antibiotic of Bacills subtilis, and a lipopeptide containing $\beta$-hydroxy fatty acids. Biochim Biophys Acta 1036:101-106.

Capozzi et al. 2017. Spontaneous food fermentations and potential risksfor human health. Fermentation 3:4968.

Cheng AC et al. 2017. Isolation and characterization of antimicrobial peptides derived from Bacillus subtilis E20-fermented soybean meal and its use for preventing Vibrio infection in shrimp aquaculture. Fish Shellfish Immunol 67:270-279.

Elayaraja et al. 2014. Production, purification, and characterization of bacteriocin from Lactobacillus murinus AU06 and its broad antibacterial spectrum. Asian Pac J Trop Biomed 4:305-311.

Hajeb P, Jinap S. 2012. Fermented shrimp products as source of Umami in Southeast Asia. J Nutr Food Sci 10:1-5.

Hovelius B, Mardh PA. 1984. Staphylococcus saprophyticus as a common cause of urinary tract infection. Rev Infect Dis 6:328-337.

Majumdar SK, Bose SK. 1958. Utilization of amino acids by Bacillus subtilis during growth and antibiotic production. Biochimica et Biophysica Acta 29:509-513.

Mok et al. 2019. A metabolomics approach to understand the solid-state fermentation of okara using Bacillus subtilis WX-17 for enhanced nutritional profile. $A M B$ Express 9:60-72.
Pongsetkul et al. 2014. Chemical composition and physical properties of salted shrimp paste (Kapi) produced in Thailand. Internatinal Aquatic Research 6:155-166.

Rhee et al. 2011. Importance of lactic acid bacteria in Asian fermented foods. Microbial Cell Factories 10:5-18.

Roos YH. 2003. Water activity-effect on food stability. In: Encyclopedia of Food Sciences and Nutrition. London: Elsevier. pp. 6094-6101.

Sakinc et al. 2005. The surface-associated protein of Staphylococcus saprophyticus is a lipase. Infect Immun 73:6419-6428.

Sandle T. 2019. Selection and Application of Culture Media. In: Biocontamination Control for Pharmaceuticals and Healthcare. Elstree: Elsevier. pp. 103-123.

[SNI] Standar Nasional Indonesia. 2016. Terasi Udang. Badan Standardisasi Nasional, ICS 67.120.30. SNI 2716:2016.

Stein T. 2005. Bacillus subtilis antibiotics: structure, syntheses, and specific functions. Molecular Microbiology 56:845-857

Tambaria MDA. 2016. Considering the Nutrional Value of Terasi and Incorporating into the Indonesian Diet. International Indonesia Forum.

United States Pharmacopeial Convention, Inc. 2001. The United States pharmacopeia 25/The national formulary 20-2002. United States Pharmacopeial Convention, Inc., Rockville, Md.

Waryono T. 2001. The History and Social Value Characterisitcs of Kampung Laud Segara Anakan Cilacap Community. In: Indonesia German Cooperation in Marine Science and Geoscience Action plan Meeting. Purwokerto: Marine Study Center University of Indonesia. 